\title{
DESTRUCTION OF BIOFILMS ON SILICONE TUBES UNDER THE ACTION OF A MIXTURE OF NOCARDIA VACCINII IMV B-7405 SURFACTANTS WITH OTHER BIOCIDES
}

\author{
T.P. Pirog ${ }^{1,2}$, L.V. Kliuchka ${ }^{1}$, T.A. Shevchuk ${ }^{2}$, G.O. Iutynska ${ }^{2}$ \\ ${ }^{I}$ National University of Food Technologies, \\ 68 Volodymyrska Str., Kyiv, 01601, Ukraine \\ ${ }^{2}$ Zabolotny Institute of Microbiology and Virology, NAS of Ukraine, \\ 154 Acad. Zabolotny Str., Kyiv, 03143, Ukraine \\ e-mail:tapirog@nuft.edu.ua
}

The formation of pathogenic microorganisms biofilms on the central venous catheter is the cause of catheter-associated infections. An alternative method of combating biofilms is the use of "antibacterial" and "antifungal" locks, which are solutions of antibiotics or antifungal drugs in a mixture with other natural compounds, which can be microbial surface-active substances (surfactants) or essential oils. Aim. To investigate the role of Nocardia vaccinii IMV B-7405 surfactants mixture with other antimicrobial compounds in the destruction of biofilm on silicone tubes. Methods. N. vaccinii IMV B-7405 was grown in medium containing as carbon source purified glycerol and waste from biodiesel production, refined sunflower oil, oil after frying French-fried potatoes, Potato wedges and meat. The surfactants were extracted from supernatant of cultural liquid by modified Folch mixture. $2 \mathrm{~mL}$ of surfactant solutions, antifungal drugs (nystatin, fluconazole) or tea tree essential oil of the same concentration $(5-640 \mu \mathrm{g} / \mathrm{mL})$ were added to test tubes with silicone tubes (with pre-formed biofilm from test culture). To study the synergistic effect of the biofilms destruction, a mixture of surfactant solutions and antifungal substances (or essential oil) of the same concentration in a ratio of 1:1 (1 $\mathrm{mL}$ of each solution) was added to the test tubes. Sterile tap water $(2 \mathrm{~mL})$ was added to control test tubes instead of surfactants preparations, antifungal substances or essential oil. The degree of biofilm destruction (\%) was determined as the difference between the adhesion of cells on the inner side of silicone tubes, untreated and treated with surfactants, antifungal drugs, essential oil, or their mixture. Results. It was found that surfactants synthesized by N. vaccinii IMV $B-7405$ on all substrates showed synergism of yeast and bacterial biofilms destruction on silicone tubes in a mixture with nystatin, fluconazole and tea essential oil in the whole range of investigated concentrations $(5-640 \mu \mathrm{g} / \mathrm{mL})$, but the highest effect was achieved at a concentration of 20-40 $\mu \mathrm{g} / \mathrm{mL}$. Thus, the degree of Candida albicans D-6, Candida utilis BVS-65 and Candida tropicalis PE-2 biofilms destruction under the action of a mixture of surfactants synthesized on waste from the biodiesel production and waste oil, with antifungal drugs was 45.8-71.8\% and was higher than with only surfactants (21.2-41.6\%), nystatin (22.4-24.1\%) or fluconazole (28.1-31.3\%). The destruction of Candida genus yeast biofilms under the action of surfactants synthesized on oil-containing substrates in a mixture with both nystatin and fluconazole reached 50.1-71.2\%, which is 10-30\% higher compared to the use of surfactants alone or only antifungal agents. The degree of Pseudomonas sp. MI-2, Escherichia coli IEM-1, Staphylococcus aureus BMS-1, Bacillus subtilis BT-2 (spores) biofilms destruction on silicone tubes treated with a mixture of tea tree essential oil and surfactants synthesized on all oil-containing substrates was 10-29\% higher than in the case of using only solutions of surfactants (11.5-45.4\%) or essential oil (21.4-34.5\%) for the tubes treatment. Conclusions. The data obtained make it possible to consider surfactants synthesized by $N$. vaccinii IMV B-7405 on a wide range of cheap and accessible substrates as promising components of "antibacterial" and "antifungal" locks in combination with essential oils and antifungal agents.

Keywords: Nocardia vaccinii IMV B-7405, surfactants, antifungal drugs, tea tree essential oil, synergism of biofilm destruction. 
Central venous (tunnelled) catheters are among the most commonly used invasive medical devices in hemodialysis procedures. The advantage of their use is the possibility of introducing into the patient's vein for a long time, which allows the necessary medical manipulations to be carried out quickly enough without injuring the venous vessels and to reduce the procedure cost $[1,2]$. However, the most common complications in the use of such devices are thrombosis and catheter-associated infections. The latter is caused by the ingress of coagulase-negative staphylococci, Staphylococcus aureus, Escherichia coli, Pseudomonas aeruginosa [3-5], yeast of the Candida genus [6, 7] into the lumen of the catheter, and the formation of biofilm. One of the most used methods of combating these pathogens is the introduction of so-called "antibacterial locks" into the lumen of tunnel catheters, which are a solution of antibiotics (amikacin, gentamicin, amphotericin B, colistin, voriconazole) with heparin [3]. At the same time, the disadvantage of using antibiotics is their rather high concentration $(5-100 \mathrm{mg} / \mathrm{mL})$ in the composition of such solutions [3] and the formation of resistance in microorganisms [8].

In our previous work [9], we noted that alternative substances that reduce the antibiotics concentration in solution and can be used as "antibacterial locks" are surfactants synthesized by Nocardia vaccinii IMV B-7405 which showing synergism of antimicrobial action with antibiotics, synthetic antifungal drugs [10] and essential oils [11]. In addition to antimicrobial, surfactants also have anti-adhesive activity, as well as the ability to destruct biofilms.

In connection with the above, the aim of this work was to investigate the role of a mixture of $N$. vaccinii IMV B-7405 surfactants with other antimicrobial compounds in the destruction of biofilms on silicone tubes.

Materials and methods. The main object of research was oil oxidizing bacteria strain Nocardia vaccinii $\mathrm{K}-8$, that was isolated from oil polluted samples of soil [12]. Strain K-8 was registered in the Depositary of Microorganisms of the DK Zabolotny Institute of Microbiology and Virology of the National Academy of Sciences of Ukraine under the number IMV B-7405.

Bacterial (Pseudomonas sp. MI-2, E. coli IEM-1, S. aureus BMS-1, Bacillus subtilis BT-2 (spores)) and yeast (Candida albicans D-6, Candida utilis BVS-65 and Candida tropicalis PE-2) strains from the collection of live cultures of the Department of
Biotechnology and Microbiology of the National University of Food Technology were used as test cultures in determining the ability to destruct biofilms.

Tea tree essential oil (Aromatica LLC, Ukraine), synthetic agent fluconazole, which is chemically derivative of triazole and polyene antibiotic nystatin were used.

N. vaccinii IMV B-7405 was grown in the synthetic nutrient medium containing $(\mathrm{g} / \mathrm{L}): \mathrm{NaNO}_{3}-$ $0.5 ; \mathrm{MgSO}_{4} \cdot 7 \mathrm{H}_{2} \mathrm{O}-0.1 ; \mathrm{CaCl} \cdot 2 \mathrm{H}_{2} \mathrm{O}-0.1$; $\mathrm{KH}_{2} \mathrm{PO}_{4}-0.1 ; \mathrm{FeSO}_{4} \cdot 7 \mathrm{H}_{2} \mathrm{O}-1$; yeast autolysate $0.5 \%(\mathrm{v} / \mathrm{v})$. As a carbon source we used: Refined oil "Oleina" (Dnipro oil extraction plant), sunflower oil after frying French-fried potatoes, Potato wedges, and meat (McDonald's fast-food restaurants, Kyiv); purified glycerol and waste from biodiesel production (biofuel plant, Poltava region) at a concentration of $2.0 \%(\mathrm{v} / \mathrm{v})$.

The amount of extracellular surfactants was determined using modified by us Bligh and Dyer method after extraction with a Folch mixture of chloroform and methanol (2:1) from the supernatant of the culture broth as described in [11].

The formation of a biofilm on silicone tubes and the determination of its destruction degree were carried out by a modified method, based on the methods described in $[13,14]$. The preliminary preparation of silicone tubes was spend as indicated in [13], the formation of biofilm and determination of its destruction degree according to the work [14]. The main modification consisted in the use of a mixture (1:1 ratio) of surfactants and antifungal substances (or essential oil) of the same concentration, which made it possible to compare the effectiveness of using monopreparations of these substances, their complex and to draw a conclusion about the synergistic destruction of biofilms.

Pre-cleaned and sterilized in an autoclave $\left(112^{\circ} \mathrm{C}\right.$, for $30 \mathrm{~min}$ ) silicone tubes (manufactured by "Wacker", Germany) $4 \mathrm{~cm}$ long were placed in sterile Vidal tubes. To form a biofilm, $1.8 \mathrm{~mL}$ of meat-peptone broth or liquid wort and $0.2 \mathrm{~mL}$ of one-day test culture suspension were added to test tubes and incubated for $24 \mathrm{~h}$ at the optimal temperature for test-culture; after that cultural liquid was poured off and another $1.8 \mathrm{~mL}$ of fresh liquid wort or meat-peptone broth and $0.2 \mathrm{~mL}$ of test culture suspension was added, and tubes were incubated again for $24 \mathrm{~h}$.

The cultural liquid was poured off after $48 \mathrm{~h}$, and $2 \mathrm{~mL}$ of surfactants, antifungal substances or a solution of tea tree essential oil of the same 
concentration $(5-640 \mu \mathrm{g} / \mathrm{mL})$ were added to test tubes with silicone tubes (pre-covered with the biofilm).

To study the synergistic effect of the biofilms destruction, a mixture of surfactants solutions and antifungal substances (or essential oil) of the same concentration $(5-640 \mu \mathrm{g} / \mathrm{mL})$ in a ratio of $1: 1(1 \mathrm{ml}$ of each solution) was added to the test tubes. Sterile tap water $(2 \mathrm{~mL})$ was added to control tubes instead of surfactant preparations, antifungal substances or essential oil.

After $24 \mathrm{~h}$ of exposure, the silicone tubes were washed three times with distilled water, placed in sterile Vidal tubes, and the biofilm was fixed with methanol for $15 \mathrm{~min}$, the remaining methanol was decanted, and silicone tubes were dried at room temperature. After that, the tubes were painted with $0.1 \%$ gentian violet solution for $30 \mathrm{~min}$. After staining, the silicone tubes were washed three times with distilled water. The dye from the inside of the tubes was removed using a $33 \%$ acetic acid solution, and the number of adhered cells was determined spectrophotometrically. The degree of biofilm destruction (\%) was determined as the difference between the adhesion of cells on the inner side of silicone tubes, untreated and treated with surfactants, antifungal drugs, essential oil, or their mixture $[13,14]$.

All experiments were performed in three replications, the number of parallel determinations in experiments ranged from three to five. Statistical processing of the experimental data was as described in previous paper [11]. The average difference was considered significant at $\mathrm{P}<0.05$.

Results. At the first stage, the possibility of using a mixture of antifungal drugs nystatin and fluconazole with surfactants synthesized by $N$. $v a$ ccinii IMV B-7405 on various substrates, including industrial wastes, was established by the destruction of Candida genus yeast biofilms (Tables 1 and 2). The data given in Table 1 show that, regardless of the substrate used (purified glycerol, waste from biodiesel production), the surfactants synthesized by $N$. vaccinii IMV B-7405 showed synergistic destruction of yeast biofilms in a mixture with nystatin and fluconazole. When using a mixture of surfactant solutions and antifungal drugs in a concentration of $20 \mu \mathrm{g} / \mathrm{mL}$, the degree of biofilms destruction was $45.8-71.8 \%$ and was higher than after the use of surfactants alone (21.2-41.6\%), nystatin (22.4-24.1\%) or fluconazole (28.1$31.3 \%)$ in similar concentrations. Note that the synergism of the yeast biofilms destruction under the action of surfactants and antifungal agents was observed in the all range of the studied concentrations $(5-640 \mu \mathrm{g} / \mathrm{mL})$, however, a high effect was achieved at a concentration of $20 \mu \mathrm{g} / \mathrm{mL}$. Similar patterns were observed when a mixture of nystatin and fluconazole with surfactants synthesized by $N$. vaccinii IMV B-7405 on oilcontaining substrates of various qualities was used to destroy yeast biofilms (Table 2), but the effective concentration of surfactants and antifungal agents was higher and amounted to $40 \mu \mathrm{g} / \mathrm{mL}$. Thus, the destruction of Candida genus yeast biofilm under the action of surfactants synthesized on oil-containing substrates, in a mixture with both nystatin and fluconazole, reached 50.1-71.2 \%, which is $10-30 \%$ higher compared with the use of surfactants or antifungal agents alone.

Note that a high degree of yeast biofilms destruction under the action of a mixture of fluconazole and nystatin with surfactants was achieved regardless of the quality of the oil used to obtain the surfactant (refined or after frying French fried potatoes or Potato wedges) (see Table 2).

At the next stage, we investigated the possibility of using a mixture of surfactants synthesized on various oil-containing substrates with tea tree essential oil to destroy bacterial biofilms on silicone tubes (Table 3). The data in table 3 indicate that all the surfactants showed synergism of biofilms destruction in a mixture with essential oil, however, a high effect was achieved when surfactants synthesized on oil after frying potatoes were added to the mixture. In this case, the biofilms destruction of the studied bacterial test cultures reached 50.1-69.5\%, while when using a mixture of essential oil and surfactants obtained on refined oil or oil after frying meat did not exceed 49.1-56.4 and $35.5-45.8 \%$, respectively.

At the same time, we note that the degree of bacterial biofilms destruction on silicone tubes treated with a mixture of tea tree essential oil and surfactants synthesized on all oil-containing substrates was 10-29\% higher compared to the use of only surfactants (11.5-45.4\%) or essential oil (21.4-34.5\%) for tube treatment.

Discussions. The first information on the ability of microorganisms to colonize central venous catheters dates back to 1982, when the adhesive properties of Staphylococcus epidermidis BSI were investigated [14]. Later, a role of bacteria (coagulase-negative staphylococci, S. aureus, E. coli, Pseudomonas aeruginosa, representatives of the Bacillus genus $[3-5,16])$, and fungi 


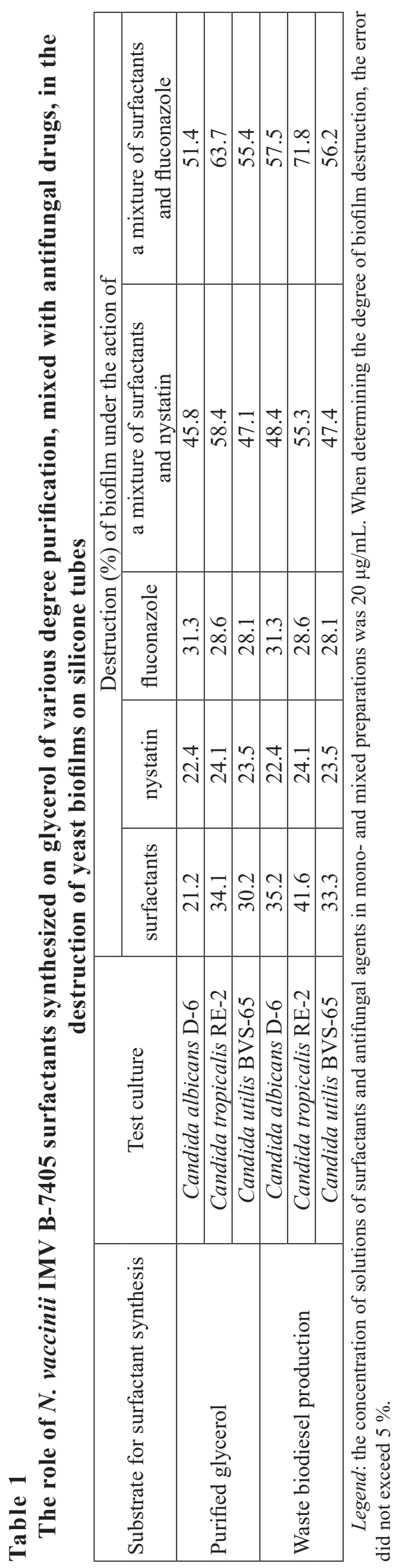

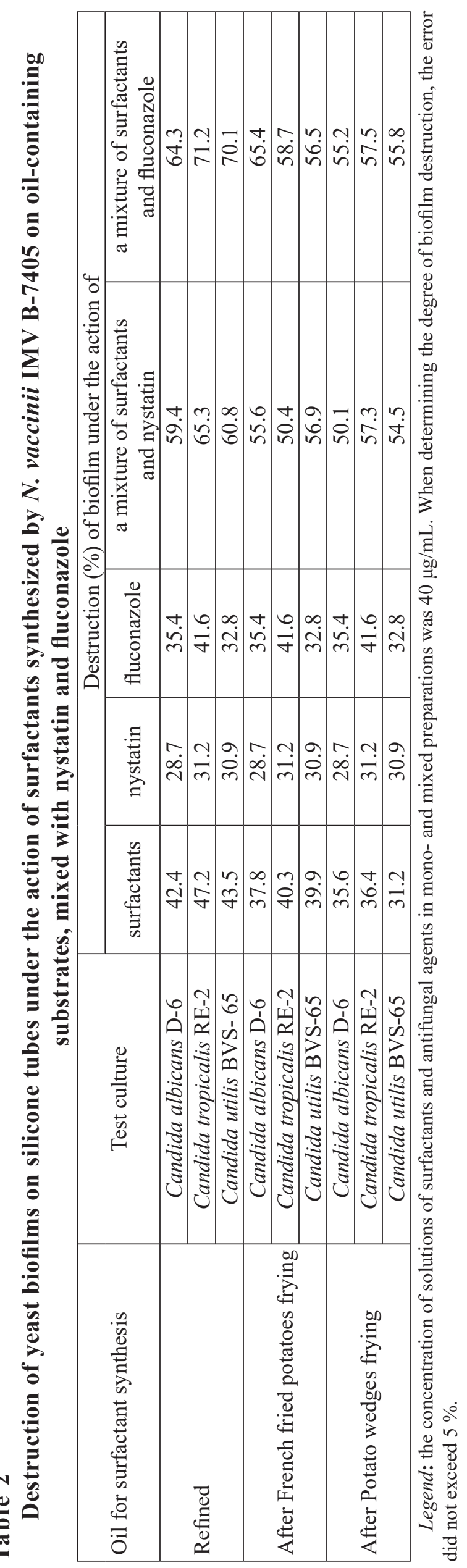

ISSN 1028-0987. Мікробіол. журн., 2021, Т. 83, № 4 


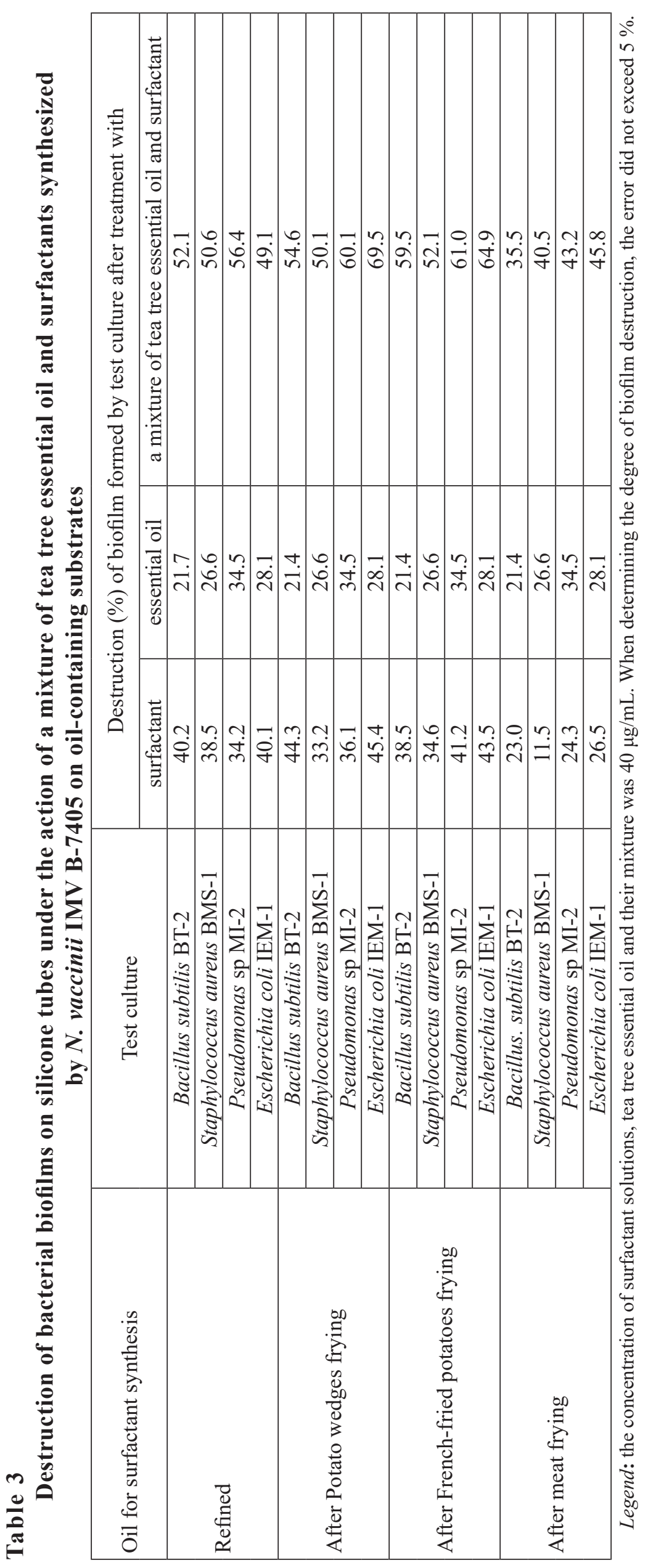


(in particular, representatives of the genus Candida $[6,7,17,18])$ in the formation of biofilms in the lumen of catheters was established.

It was shown that the risk of biofilm formation depends on the type of material used: Teflon, silicone, polyurethane are characterized by lower adhesive properties than polyvinylchloride or polyethylene $[14,19]$. These studies stimulated the search for methods of combating pathogens of catheter-associated infections, involving the use of a mixture of antibiotics with blood anticoagulants, called "antibacterial locks" $[3,20,21]$, and substances other than antibiotics, such as EDTA (ethylenediaminetetraacetate), citrate, $70 \%$ ethanol $[22,23]$ or nitric oxide nanoparticles [24].

The above data on the microorganisms of the causative agents of catheter-associated infections and the type of catheter material became the theoretical basis for the selection of test cultures and silicone as a material for biofilm formation in this work.

Another question that needs discussion is a choice of substrates to obtain the surfactants, in particular, the use of industrial wastes. First, the use of such substrates allows not only to significantly reduce the cost of surfactants, but also to dispose of toxic industrial waste. Secondly, in previous studies, the ability of surfactants synthesized by $N$. vaccinii IMV B-7405 using waste from biodiesel production [25] and waste oil [11] to destroy bacterial and yeast biofilms on polystyrene was established. Thirdly, the type of substrate for surfactant biosynthesis affects their possible potential use in the composition of "antibacterial locks", since when the solution is injected into the lumen of the catheter, there is no contact with biological fluids, and after removing the solution, the catheter is washed with saline.

The next question that needs discussion is the choice of the synergist substances that will be used in a mixture with microbial surfactants. Nystatin and fluconazole were chosen because they are the most commonly used antifungal drugs in the group of polyene antibiotics and triazole derivatives, respectively. However, the effectiveness of their use for the biofilms destruction of representatives of the Candida genus depends on the stage of biofilm development, which in turn limits the use of these antifungal drugs in comparison, for example, with amphotericin B [26]. Thus, the effective concentration of nystatin and fluconazole, which leads to degradation of 24-hour biofilm, is 0.5 and $1.8 \mu \mathrm{g} / \mathrm{mL}$, and 72 -hour -8 and $128 \mu \mathrm{g} / \mathrm{mL}$, respectively [26]. These literature data are consistent with the results obtained in this work. Thus, the effective concentration of these antifungal drugs for the destruction of C. albicans D-6, C. utilis BVS-65 and C. tropicalis PE-2 biofilms formed within 48 hours, was $20-40 \mu \mathrm{g} / \mathrm{mL}$. But even at such concentrations, the percentage of yeast biofilms destruction was low (22.4-41.6), but increased by 1.3-2.2 times in the presence of N. vaccinii IMV B-7405 surfactant (see Tables 1 and 2). Probably, the increase in the efficiency of biofilms destruction under the action of nystatin and fluconazole in combination with surfactants is due to the mechanism of action of the latter, which consists in disrupting the function of the cytoplasmic membrane, facilitating the access of antifungal compounds into the biofilm.

In the available literature, we were unable to find information on the use of a mixture of microbial surfactants with nystatin or fluconazole to destroy biofilm. At the same time, work [27] reports on the possibility of trehalose lipids synthesized by Rhodococcus fascians BD8 at a concentration of $0.25 \mu \mathrm{g} / \mathrm{L}$ to inhibit the biofilm of Candida albicans SC5314 on silicone catheters. In another work [28], there is information on the treatment of a silicone surface with a mixture of lipopeptides $(2 \mathrm{mg} / \mathrm{mL})$ synthesized by $B$. subtilis AC7 and fluconazole $(2 \mathrm{mg} / \mathrm{mL}$ ) to prevent the formation of Candida albicans 40 biofilm.

A review published in 2018 [26] summarized the data available at that time on the use of antifungal drugs, including nystatin and fluconazole, as part of "antifungal locks" to destroy formed biofilms. The newest works concern the use of antifungal agents for the biofilms destruction in combination with natural compounds, in particular essential oils $[29,30]$ and other plant extracts [31]. In works [29-31] it is noted that the use of a mixture of antimicrobial compounds made it possible to reduce the concentration of antifungal drugs and increase their effectiveness. For example, under the action of a mixture of fluconazole $(16 \mu \mathrm{g} / \mathrm{mL})$ and pseudolaric acid (diterpenic acid, is the main antifungal component of a Chinese herb known as "Tu-Jin-Pi", which is prescribed to treat fungal skin infections) at a concentration of $4 \mu \mathrm{g} / \mathrm{mL}$ destruction of C. tropicalis ATCC 750 biofilm reached $80.3 \%$ [31]. At the same time, the monopreparation of fluconazole in the studied concentration not acted on the biofilm. Note that the number of currently used drugs, acting against yeast and, mainly, bacterial catheter-associated infections pathogens, is limited, due to the high resistance of microorganisms against the background of the use 
of unreasonably high doses of antifungal drugs and antibiotics [3, 20, 27].

The use of natural compounds (essential oils or their main components) is one of the approaches to increasing the effectiveness of antimicrobial compounds. Therefore, at the next stage, we investigated the possibility of using a mixture of tea tree essential oil and N. vaccinii IMV B-7405 surfactants synthesized on oil-containing substrates for the destruction of bacterial biofilms on silicone (Table 3).

The choice of tea tree essential oil as a synergistic substance was due to the following reasons. Firstly, this essential oil is one of the few described in the European Pharmacopoeia and approved for use; the main components are represented by monoterpenes (1,8-cineole, linalool, terpinen-4-ol or $\alpha$-terpineol), which easily penetrate the cytoplasmic membrane of both grampositive and gram-negative bacteria [32]. Secondly, surfactants synthesized by $N$. vaccinii IMV B-7405 showed synergism of antimicrobial action with tea tree oil, as well as in the destruction of biofilms on polystyrene [11].

Our studies have shown that the degree of Pseudomonas sp. MI-2, E. coli IEM-1, S. aureus BMS-1, B. subtilis BT-2 (spores) biofilm destruction on silicone tubes under the action of surfactants synthesized on oil after frying meat was lower $(11.5-26.5 \%)$ than in the case of using surfactants obtained on other oil-containing substrates (33.2-45.4\%). In our opinion, this can be explained as follows. One of the mechanisms of biofilm destruction in the presence of microbial surfactants is their antimicrobial activity [33], and in [34] we found that surfactants synthesized by N. vaccinii IMV B-7405 on oil after frying meat are characterized by low antimicrobial activity, which is due to the low content of aminolipids in the composition of such surfactants, which are responsible for antimicrobial properties. At the same time, the destruction of test cultures biofilms under the action of a mixture of essential oil and surfactants synthesized in oil after meat frying and other oil-containing substrates was higher $(35.5-69.5 \%)$ than in the presence of surfactants (11.5-45.4\%), or only essential oil (21.4-34.5\%) (see Table 3).

In the published review [35], we focused on the fact that in the literature there are only few data on the influence of the cultivation conditions of surfactant producers on their biological properties. Our results indicate that the surfactants synthesized by $N$. vaccinii IMV B-7405 on all substrates, including industrial waste, showed synergy with other biocides in bacteria and yeast biofilm destruction.

In the literature, we were unable to find data about the biofilms destruction under the action of a mixture of surfactants and essential oils, since in most dates such properties are determined for a complex of an essential oil and an antibiotic $[36,37]$ or several oils or their components [38].

Thus, for example, in [37] it was shown the destruction of biofilm formed by Pseudomonas aeruginosa ATCC 10145 - causative agent of nosocomial catheter associated infections under the action of tea tree essential oil $(5 \%, \mathrm{v} / \mathrm{v})$ in a mixture with ciprofloxacin $(10 \mu \mathrm{g} / \mathrm{mL})$. In [38], the authors established a synergistic effect of thymol (the main component of tea tree essential oil) and muporocin at a concentration of $0.5 \mathrm{mg} / \mathrm{mL}$ and $2 \mathrm{mg} / \mathrm{mL}$, respectively, in the destruction of S. aureus MFBF 10680 biofilm. When thymol was added to muporocin, the destruction of biofilm increased to $45-60 \%$ compared to using antibiotic alone (20-34\%).

Conclusions. So, our results on the use of microbial surfactants in a mixture with fluconazole, nystatin and tea tree essential oil to destroy yeast and bacterial biofilms on silicone tubes are pioneering. These data allow us to consider surfactants synthesized by $N$. vaccinii IMV B-7405 on a wide range of cheap and accessible substrates as promising components of "antibacterial" and "antifungal" locks in combination with essential oils and antifungal agents. 


\section{РУЙНУВАННЯ БІОПЛІВОК \\ НА СИЛІКОНОВИХ ТРУБКАХ \\ ЗА ДІЇ СУМІШІ ПОВЕРХНЕВО- АКТИВНИХ РЕЧОВИН \\ NOCARDIA VACCINII IMB B-7405 \\ 3 ІНШИМИ БІОЦИДАМИ}

Т.П. Пирог ${ }^{1,2}$, Л.В. Ключка ${ }^{1}$,

Т.А. Шевчук ${ }^{2}$, Г.О. Уутинська

${ }^{1}$ Національний університет харчових технологій, вул. Володимирська, 68, Київ, 01601, Україна

${ }^{2}$ Інститут мікробіології і вірусологї ім. Д.К. Заболотного НАН України, вул. Академіка Заболотного, 154, Київ, 03143, Україна

Резюме

Формування біоплівок патогенних мікроорганізмів на центральних венозних катетерах $€$ причиною виникнення катетер-асоційованих інфекцій. Альтернативним методом боротьби з біоплівками є використання «антибатеріальних» та «антифунгальних» замків, що являють собою розчини антибіотиків чи антифунгальних препаратів у суміші з іншими природними сполуками, якими можуть бути мікробні поверхнево-активні речовини (ПАР) або ефірні олії. Мета. Дослідити роль суміші поверхнево-активних речовини Nocardia vaccinii IMB B-7405 з іншими антимікробними сполуками у руйнуванні біоплівки на силіконових трубках. Методи. N. vaccinii IMB В-7405 вирощували у середовищі, що містило як джерело вуглецю очищений гліцерин та відходи виробництва біодизелю, рафіновану соняшникову олію, а також олію після смаження картоплі «фрі», картоплі селянської та м'яса. Поверхнево-активні речовини екстрагували з супернатанту культуральної рідини модифікованою сумішшю Фолча. У пробірки з силіконовими трубками (з попередньо сформованою на них біоплівкою тест-культури) вносили по 2 мл розчинів ПАР, антифунгальних препаратів (ністатин, флуконазол) або ефірної олії чайного дерева однакової концентрації (5-640 мкг/мл). Для дослідження синергічного ефекту руйнування біоплівок у пробірки вносили суміш розчинів ПАР та антифунгальних речовин (чи ефірної олії) однакової концентрації у співвідношенні 1:1 (по 1 мл кожного розчину). У контрольні пробірки замість препаратів ПАР, антифунгальних речовин або ефірної олії вносили стерильну водопровідну воду (2 мл). Ступінь руйнування біоплівки (\%) визначали як різницю між адгезією клітин на внутрішній стороні силіконових трубок, необроблених і оброблених ПАР, антифунгальними препаратами, ефірною олією або їх сумішшю. Результати. Встановлено, що поверхнево-активні речовини, синтезовані $N$. vaccinii IMB В-7405 на усіх субстратах, проявляли синергізм деструкції дріжджових та батеріальних біоплівок на силіконових трубках у суміші з ністатином, флуконазолом та ефірною олією чайного дерева у всьому діапазоні досліджуваних концентрацій (5-640 мкг/мл), проте найвищий ефект досягався за концентрації препаратів 20-40 мкг/мл. Так, ступінь руйнування біоплівок Candida albicans Д-6, Candida utilis БВС-65 та Candida tropicalis PE-2 за дії суміші ПАР, синтезованих на відходах виробництва біодизелю та відпрацьованій олії, з антифунгальними препаратами становив 45.8-71.8 \% і був вищим, ніж за дії тільки ПАР (21.2-41.6\%), ністатину (22.4-24.1 \%) чи флуконазолу (28.1-31.3\%). Деструкція біоплівок дріжджів роду Candida за дії ПАР, синтезованих на олієвмісних субстратах, у суміші як з ністатином, так і флуконазолом досягала 50.1-71.2 \%, що на 10-30 \% вище порівняно iз застосуванням тільки ПАР або тільки антифунгальних засобів. Ступінь руйнування біоплівок Pseudomonas sp. MI-2, Escherichia coli IEM-1, Staphylococcus aureus БMC-1, Bacillus subtilis БТ-2 (спори) на силіконових трубках, оброблених сумішшю ефірної олії чайного дерева і ПАР, синтезованих на усіх олієвмісних субстратах, був на 1029 \% вищим, ніж у разі використання для обробки трубок лише розчинів поверхнево-активних речовин (11.5-45.4 \%) чи ефірної олії (21.4-34.5\%). Висновки. Отримані дані дають змогу розглядати поверхнево-активні речовини, синтезовані N. vaccinii IMB B-7405 на широкому наборі дешевих і доступних субстратів як перспективні складові «антибактеріальних» та «антифунгальних» замків у комплексі з ефірними оліями та антифунгальними засобами.

Ключові слова: Nocardia vaccinii IMB B-7405, поверхнево-активні речовини, антифунгальні препарати, ефірна олія чайного дерева, синергізм руйнування біоплівок. 
1. Akaraborworn O. A review in emergency central venous catheterization. Chin J Traumatol. 2017; 20(3):137-40. doi:10.1016/j.cjtee.2017.03.003.

2. Abbasi SH, Aftab RA, Chua SS. Risk factors associated with nosocomial infections among end stage renal disease patients undergoing hemodialysis: A systematic review. PLoS One. 2020; 15(6):e0234376. doi:10.1371/journal. pone. 0234376 .

3. Zanwar S, Jain P, Gokarn A, Devadas SK, Puna$\operatorname{tar}$ S, Khurana S, et al. Antibiotic lock therapy for salvage of tunneled central venous catheters with catheter colonization and catheter-related bloodstream infection. Transpl Infect Dis. 2019; 21(1):e13017. doi:10.1111/tid.13017.

4. Mandolfo S, Anesi A, Maggio M, Rognoni V, Galli F, Forneris G. High success rate in salvage of catheter-related bloodstream infections due to Staphylococcus aureus, on behalf of project group of Italian society of nephrology. J Vasc Access. 2020; 21(3):336-41. doi:10.1177/1129729819875323.

5. Aminzadeh Z, Simpson P, Athan E. Central venous catheter associated blood stream infections (CVC-BSIs) in the non-intensive care settings: Epidemiology, microbiology and outcomes. Infect Dis Health. 2019; 24(4):222-8. doi:10.1016/j.idh.2019.07.003.

6. Bekçibaşi M, Dayan S, Aslan E, Kortak MZ, Hoşoğlu S. Risk factors for central venous catheter-related bloodstream infections. Infez Med. 2019; 27(3):258-65.

7. Tatsuno K, Ikeda M, Wakabayashi Y, Yanagimoto S, Okugawa S, Moriya K. Clinical features of bloodstream infections associated with peripheral versus central venous catheters. Infect Dis Ther. 2019; 8(3):343-52. doi:10.1007/s40121019-00257-6.

8. Burnham JP, Rojek RP, Kollef MH. Catheter removal and outcomes of multidrug-resistant central-line-associated bloodstream infection. Medicine (Baltimore). 2018; 97(42):e12782. doi:10.1097/MD.0000000000012782

9. Pirog TP, Nikituk LV, Shevchuk TA. [Synergism of antimicrobial activity of Nocardia vaccinii IMV B-7405 surfactants and antibiotics].
Mikrobiol Z. 2017; 79(4):30-9. doi:https://doi. org/10.15407/microbiolj79.04.030. Ukrainian.

10. Pirog TP, Nikitiuk LV. [Synergistic action of Nocardia vaccinii IMV B-7405 surfactants and antifungal agents] Scientific Works of NUFT. 2017; 23(1):58-65. Ukrainian.

11. Pirog TP, Kliuchka LV, Kliuchka IV, Shevchuk TA, Iutynska GO. Synergism of antimicrobial and anti-adhesive activity of Nocardia vaccinii IMV B-7405 surfactants in a mixture with essential oils. Mikrobiol Z. 2020; 82(4):31-40. doi:https://doi.org/10.15407/microbiolj82.04.031.

12. Pirog TP, Shevchuk TA, Voloshina IN, Gregirchak NN. Use of claydite-immobilized oil-oxidizing microbial cells for purification of water from oil. Appl Biochem Microbiol. 2005; 41(1): 51-5. https://doi.org/10.1007/s10438-0050010-z

13. Kim DJ, Park JH, Chang M. Species-specific characteristics of the biofilm generated in silicone tube: an in vitro study. BMC Ophthalmol. 2018. https://doi.org/10.1186/s12886-018-07501.

14. Gomes M-ZV, Nitschke M. Evaluation of rhamnolipids surfactants as agents to reduce the adhesion of Staphylococcus aureus to polystyrene surfaces. Lett Appl Microbiol. 2012; 49(1):960 65.

15. Gominet M, Compain F, Beloin C, Lebeaux D. Central venous catheters and biofilms: where do we stand in 2017? APMIS. 2017; 125(4):365-75. doi:10.1111/apm.12665/

16. Ikram S, Heikal A, Finke S, Hofgaard A, Rehman Y, Sabri AN, et al. Bacillus cereus biofilm formation on central venous catheters of hospitalised cardiac patients. Biofouling. 2019; 35(2):204-16. doi:10.1080/08927014.2019.158 6889.

17. Taff HT, Marchillo K, Andes DR. Preparation of Candida albicans biofilms using an in vivo rat central venous catheter model. Bio Protoc. 2013; 3(14):e823. doi:10.21769/bioprotoc.823.

18. Reitzel RA, Rosenblatt J, Gerges BZ, Vargas-Cruz N, Raad II. Minocycline-EDTA-ethanol antimicrobial catheter lock solution is highly 
effective in vitro for eradication of Candida auris biofilms. Antimicrob Agents Chemother. 2020; 64(4):e02146-19.

19. Sousa C, Teixeira P, Oliveira R. Influence of surface properties on the adhesion of Staphylococcus epidermidis to acrylic and silicone. Int J Biomater. 2009; 2009:718017. doi:10.1155/2009/718017.

20. Böhlke M, Uliano G, Barcellos FC. Hemodialysis catheter-related infection: prophylaxis, diagnosis and treatment. J Vasc Access. 2015; 16(5):347-55. doi:10.5301/jva.5000368.

21. Freire MP, Pierrotti LC, Zerati AE, Benites L, da Motta-Leal Filho JM, Ibrahim KY, et al. Role of lock therapy for long-term catheter-related infections by multidrug-resistant bacteria. Antimicrob Agents Chemother. 2018; 62(9):e00569-18. doi:10.1128/AAC.00569-18.

22. Chauhan A, Lebeaux D, Ghigo JM, Beloin C. Full and broad-spectrum in vivo eradication of catheter-associated biofilms using gentamicin-EDTA antibiotic lock therapy. Antimicrob Agents Chemother. 2012; 56(12):6310-8. doi:10.1128/ AAC.01606-12.

23. Labriola L, Pochet JM. Any use for alternative lock solutions in the prevention of catheter-related blood stream infections? J Vasc Access. 2017; 18(1):34-8. doi:10.5301/jva.5000681.

24. Ahmadi MS, Lee HH, Sanchez DA, Friedman AJ, Tar MT, Davies KP, et al. Sustained nitric oxide-releasing nanoparticles induce cell death in Candida albicans yeast and hyphal cells, preventing biofilm formation in vitro and in a rodent central venous catheter model. Antimicrob Agents Chemother. 2016; 60(4):2185-94. doi:10.1128/AAC.02659-1

25. Pirog TP, Klyuchka IV, Klyuchka LV, Shevchuk TA, Iutynska GO. [Destruction of biofilms under the action of surfactants synthesized in different cultivation conditions Nocardia vaccinii IMV B-7405]. Mikrobiol Z. 2019; 81(5):3-15. doi:https://doi.org/10.15407/microbiolj81.05.003. Ukrainian.

26. Cavalheiro M, Teixeira MC. Candida Biofilms: threats, challenges, and promising strategies. Front Med (Lausanne). 2018; 5:28. doi:10.3389/ fmed.2018.00028.
27. Janek T, Krasowska A, Czyżnikowska Ż, Łukaszewicz M. Trehalose lipid biosurfactant reduces adhesion of microbial pathogens to polystyrene and silicone surfaces: an experimental and computational approach. Front Microbiol. 2018; 9(2441), doi:10.3389/fmicb.2018.02441.

28. Ceresa C, Rinaldi M, Fracchia L. Synergistic activity of antifungal drugs and lipopeptide AC7 against Candida albicans biofilm on silicone. AIMS Bioengineering. 2017; 4(2):318-34. doi:10.3934/bioeng.2017.2.318.

29. Jafri H, Banerjee G, Khan M, Ahmad I, Abulreesh $\mathrm{HH}$, Althubiani AS. Synergistic interaction of eugenol and antimicrobial drugs in eradication of single and mixed biofilms of Candida albicans and Streptococcus mutans. AMB Express. 2020; 10(1):185. https://doi.org/10.1186/s13568-02001123-2.

30. Jafri H, Ahmad I. Thymus vulgaris essential oil and thymol inhibit biofilms and interact synergistically with antifungal drugs against drug resistant strains of Candida albicans and Candida tropicalis. J Mycol Med. 2020; 30(1):100911. doi:10.1016/j.mycmed.2019.100911.

31. Li Z, Yin H, Chen W, Jiang C, Hu J, Xue Y, et al. Synergistic effect of pseudolaric acid b with fluconazole against resistant isolates and biofilm of Candida tropicalis. Infect Drug Resist. 2020; 13:2733-43. doi: 10.2147/IDR.S261299.

32. D'agostino M, Tesse N, Frippiat JP, Machouart M, Debourgogne A. Essential oils and their natural active compounds presenting antifungal properties. Molecules. 2019; 24(20):3713. doi:10.3390/ molecules 24203713

33. Zhao H, Shao D, Jiang C, Shi J, Li Q, Huang Q, et al. Biological activity of lipopeptides from Bacillus. Appl Microbiol Biotechnol. 2017; 101(15):5951-60. doi:10.1007/s00253-0178396-0.

34. Pirog TP, Nikituk LV, Antonuk SI, Shevchuk TA, Iutynska GO. [Peculiarities of Nocardia vaccinii IMV B-7405 surfactants synthesis on waste oil of different quality and their antimicrobial properties]. Mikrobiol Z. 2017; 79(2):13-22. doi:https://doi.org/10.15407/microbiolj79.02.013. Ukrainian. 
35. Pirog TP, Klyuchka LV, Shevchuk TA, Muchnyk FV. [Interrelation of chemical composition and biological properties of microbial surfactants]. Mikrobiol Z. 2019; 81(3):84-104. Ukrainian. doi:https://doi.org/10.15407/microbiolj81.03. 084 .

36. Algburi A, Comito N, Kashtanov D, Dicks LMT, Chikindas ML. Control of biofilm formation: antibiotics and beyond. Appl Environ Microbiol. 2017; 83(3):e02508-16. doi:10.1128/AEM. 02508-16.

37. Coelho LF, Pereira MO. Exploring new treatment strategies for Pseudomonas aeruginosa biofilm infections based on plant essential oils. In: Microbial pathogens and strategies for combating them: science, technology and education (Ed. Méndez-Vilas A). Badajoz: Formatex Research Center, 2013; 83-9. http://hdl.handle. net/1822/33087.

38. Kifer D, Mužinić V, Klarić MŠ. Antimicrobial potency of single and combined mupirocin and monoterpenes, thymol, menthol and 1,8-cineole against Staphylococcus aureus planktonic and biofilm growth. J Antibiot (Tokyo). 2016; 69(9):689-96. doi:10.1038/ja.2016.10.

Received 14.04.2021 